\title{
RUMAH PENCU DI KUDUS: Kajian Berdasarkan Tipologi dan Pola Sebaran
}

\author{
PENCU HOUSE IN KUDUS: \\ A Study on Typology and Dispersion Pattern
}

\author{
Imam Nazaruddin \\ Alumni Jurusan Arkeologi FIB - UGM
}

\begin{abstract}
This study discusses about the traditional houses one of the houses contained in the Holy Pencu home. Pencu home has architectural joglo shaped and has a distribution contained in the Holy Ghost and Wetan Kulon. This study aimed to objective is to know the types of Pencu houses resulting from the classification based on arsitectural, and able to explain the difference between Kudus Kulon and Kudus Wetan Pencu house based on distribution patterns. The results of this study produced six classifications based on the architecture of the house spread Pencu contained Kudus, namely types $A, B, C, D, E$, and $F$. The presence of the type of Pencu houses indicate levels of hierarchy in the distribution of Pencu house in Kudus. Kudus Kulon, has more types of variation and the density is very high compared with that of the Kudus Wetan. Pencu type of house it shows the pattern of settlement distribution center that has a pattern of getting away from the central location of the lower levels of the type of home Pencu. This condition indicates that the Holy of Kulon is the axis / central of the traditional culture of the Kudus people.
\end{abstract}

Keywords: Pencu House, Kudus, Typology

\begin{abstract}
ABSTRAK
Penelitian ini membahas mengenai rumah salah satu rumah tradisional yang terdapat di Kudus yaitu rumah Pencu. Rumah Pencu memiliki arsitektur yang berbentuk joglo dan memiliki persebaran yang terdapat di wilayah Kudus Kulon dan Kudus Wetan. Penelitian ini bertujuan untuk mendapatkan gambaran mengenai tipe-tipe rumah Pencu yang dihasilkan dari klasifikasi berdasarkan arsiteturalnya, dan menjelaskan perbedaan antara Kudus Kulon dan Kudus Wetan berdasarkan pola sebaran rumah Pencu. Hasil penelitian ini menghasilkan enam klasifikasi berdasarkan arsitektur dari persebaran rumah Pencu yang terdapat di Kudus, yaitu tipe A, B, C, D, E, dan F. Terdapatnya tipe rumah Pencu menunjukkan adanya tingkatan hierarki dalam persebaran rumah Pencu di Kudus. Kudus Kulon memiliki variasi tipe yang lebih banyak dan kerapatannya sangat tinggi dibandingkan dengan Kudus Wetan yang mempunyai tingkat kerapataan sangat rendah dengan pola cenderung menyebar secara acak dan tidak membentuk klaster tertentu. Terdapatnya tipe rumah Pencu tersebut menunjukan adanya pola pemukiman pusat yang memiliki pola sebaran semakin jauh dari lokasi pusat maka akan semakin rendah tingkatan tipe dari rumah Pencu tersebut. Kondisi ini menunjukkan bahwa Kudus Kulon merupakan poros/central dari kebudayaan tradisional masyarakat Kudus.
\end{abstract}

Kata kunci: Rumah Pencu, Kudus, Tipologi 


\section{PENDAHULUAN}

\section{Rumah Bagi Masyarakat Kudus Kulon dan Kudus Wetan}

Bagi masyarakat tradisional, rumah dibangun/didirikan, dihuni, dan gunakan, bukan sekedar untuk mewadahi kegiatan fisik belaka yang hanya mempertimbangkan segi kegunaan praktis, seperti untuk tidur, bekerja, dan membina keluarga. Bagi mereka rumah merupakan ungkapan alam khayal dalam wujud nyata yang mewakili alam semesta, serta adanya bayangan dan mitos terhadap sesuatu (dewa-dewa) yang memiliki kekuatan atau kekuasaan yang mengatur alam ini sudah meliputi alam pikirannya. Oleh karena itu, membangun sebuah rumah berarti menciptakan sebuah "alam kecil" di alam semesta, sehingga dianggap memulai hidup baru (Said, 2004: 49).

Uraian di atas menunjukkan pentingnya arti rumah bagi suatu masyarakat. Dengan kata lain, rumah bukan sekedar hasil budaya jasmani/bendawi saja, tetapi juga berhubungan dengan berbagai pengetahuan tentang teknik, politik, sosial, ekonomi, kepercayaan, hukum, politik, aspek kejiwaan, sejarah, dan aspek-aspek pengetahuan lainnya (Soekiman, 1986: 6). Singkatnya, pengetahuan tentang rumah mencakup suatu pengertian yang membutuhkan pemahaman secara luas dan mendalam.

Pada masyarakat Kudus rumah merupakan salah satu dari hasil kebudayaan materi yang dihasilkan dari proses panjang kebudayaan masyarakat tersebut. Keberadaan rumah tradisional di Kudus memiliki keberagaman, yaitu rumah Pencu dan rumah Payon (rumah Payon Limasan Maligi Gajah dan rumah Payon Kampung).

Rumah Pencu yang terdapat di Kudus tersebar di wilayah Kudus Kulon dan Kudus Wetan. Di Kudus Kulon kondisi eksisting rumah Pencu sekarang ini masih bisa dijumpai dengan jumlah yang cukup banyak jika dibandingkan dengan kondisi eksisting rumah Pencu di daerah Kudus Wetan. Adanya perbedaan jumlah yang sangat signifikan tersebut sangat erat kaitannya dengan perkembangan lingkungan dan tata ruang di kedua wilayah tersebut. Di Kudus Kulon kondisi lingkungannya relatif tidak banyak mengalami perubahan dari tahun ke tahun, sedangkan di Kudus Wetan perubahan lingkungannya begitu pesat.

Berbeda dengan kondisi di Kudus Kulon, perkembangan pemukiman di Kudus Wetan sudah banyak dipengaruhi unsur-unsur kolonial. Kudus Wetan sekarang ini merupakan pusat pemerintahan kabupaten Kudus, baik pada zaman Hindia Belanda maupun setelah kemerdekaan. Daerah ini pada zaman Belanda merupakan tempat pemukiman orang-orang Eropa dan perkampungan Cina. Di sepanjang alun-alun menuju arah timur terdapat pemukiman orang-orang Belanda. Kudus wetan mempunyai alun-alun yang biasa disebut Simpang Tujuh. Di sebelah barat alun-alun terdapat masjid besar dan di sebelah utaranya terpat kantor dan rumah kediaman Bupati Kudus (Wardani, 1991: 33).

Tulisan ini berusaha mengangkat tentang bagaimana tipologi dan pola persebaran rumah Pencu yang terdapat di Kudus. Cakupan dari daerah/wilayah penelitian yang dilakukan oleh Penulis dalam kaitannya dengan rumah Pencu adalah di Kecamatan Kota dan Kecamatan Jati yang merupakan bagian dari wilayah Kabupaten Kudus. Di dua wilayah kecamatan inilah tersebar rumah Pencu yang kemudian diangkat oleh peneliti untuk dikaji dalam penelitian ini.

Menurut Mundardjito (1986), pola pemukiman kuna terbagi dalam tiga skala persebaran berdasarkan data sejarah masa lampau yaitu: 1) skala mikro yang mengkaji pola ruang dan hubungan antar ruang dalam sebuah bangunan, 2) skala semi - mikro atau meso yang mengkaji pola-pola sebaran dan hubungannya dalam satu situs, 3) skala makro yang mengkaji pola-pola sebaran dan hubungannya dalam satu wilayah (Mundardjito, 1986: 22-23). Arsitektur rumah-rumah Pencu yang terdapat di Kudus termasuk ke dalam kajian mikro yang bertujuan mengkaji komponen-komponen arsitektur yang berkaitan dengan rumah Pencu. Hasil dari pengkajian tersebut berupa pengklasifikasian tipe rumah Pencu yang didasarkan pada unsur-unsur arsitektur rumah, sehingga membentuk adanya tipologi. Tujuan pengklasifikasian tersebut berkaitan 
dengan hubungan spasial (keruangan) yang bersifat meso atau semi - mikro dalam sebuah wilayah penelitian dapat membantu peneliti dalam meilihat pola sebaran rumah Pencu.

Penelitian ini menggunakan metode analisis spasial dengan perangkat Geographic Information System (GIS) software ArcView 3.2. yang memberikan kemudahan dalam melakukan analisis hingga interpretasi termasuk pengelolaan basis data untuk keperluan pengelompokan data sampai pada tahapan pengklasifikasian data, sehingga dapat memudahkan Penulis dalam membuat tipologi.

\section{PERSEBARAN RUMAH PENCU DI KUDUS}

Melacak mengenai berdirinya sebuah rumah tradisional, khususnya rumah tradisional Jawa sangatlah bergantung mengenai ketersediaan data tertulis yang mendukung keberadaan rumah-rumah tersebut. Kesukaran ini muncul dikarenakan sifat dari rumah Jawa yang termasuk dalam kategori folk tradition yang bersifat anonym dan berkembang turun temurun melalui media tutur lisan dalam lingkungan masyarakat setempat tanpa dapat diketahui kapan mulai diciptakan dan siapa perancang atau pemilik pertamanya. Hal ini terjadi pula terhadap rumah tradisional yang ada di Kudus. Dari rumah-rumah tradisonal yang terdapat di kota Kudus hanya sedikit yang bisa diketahui penanggalan yang terkait dengan pendirian bangunan tersebut.

Bentuk atap dari rumah Pencu memang berbeda dengan rumah joglo pada umumnya, kontruksi atap rumah ini lebih tinggi dibandingkan dengan kontruksi atap rumah tipe joglo lainnya. Adanya bentuk atap tersebut yang menyebabkan rumah joglo Kepuhan Limolasan ini oleh masyarakat Kudus disebut sebagai omah Pencu, yang berarti muncak, mucuk, atau menjulang tinggi.

Pada tahun 2003 tim peneliti dari Balai Pelestarian Peninggalan Purbakala (BP3) Jawa Tengah mengadakan inventarisasi rumah adat Kudus yang mencakup wilayah kecamatan Kota. Hasil inventarisasi yang dilakukan oleh tim BP3 Jateng tersebut berhasil menginventarisasikan 33 rumah tradisional Kudus. Berdasarkan inventarisasi yang dilakukan oleh Dinas Pariwisata dan Kebudayaan Kabupaten Kudus pada tahun 2007 berjumlah 63 rumah tradisional dengan persebaran di Kudus Kulon berjumlah 58 rumah dan di Kudus Wetan 5 rumah. Adanya penambahan hasil inventarisasi yang dilakukan oleh Dinas Pariwisata dan Kebudayaan menandakan bahwa inventarisasi yang pernah dilakukan pada tahun 2003 oleh tim BP3 belumlah maksimal. Namun tidak menutup kemungkinan inventarisasi persebaran rumah tradisional Kudus pada tahun 2007 tersebut juga belum semua rumah tradisional yang ada di Kudus terinventasasi.

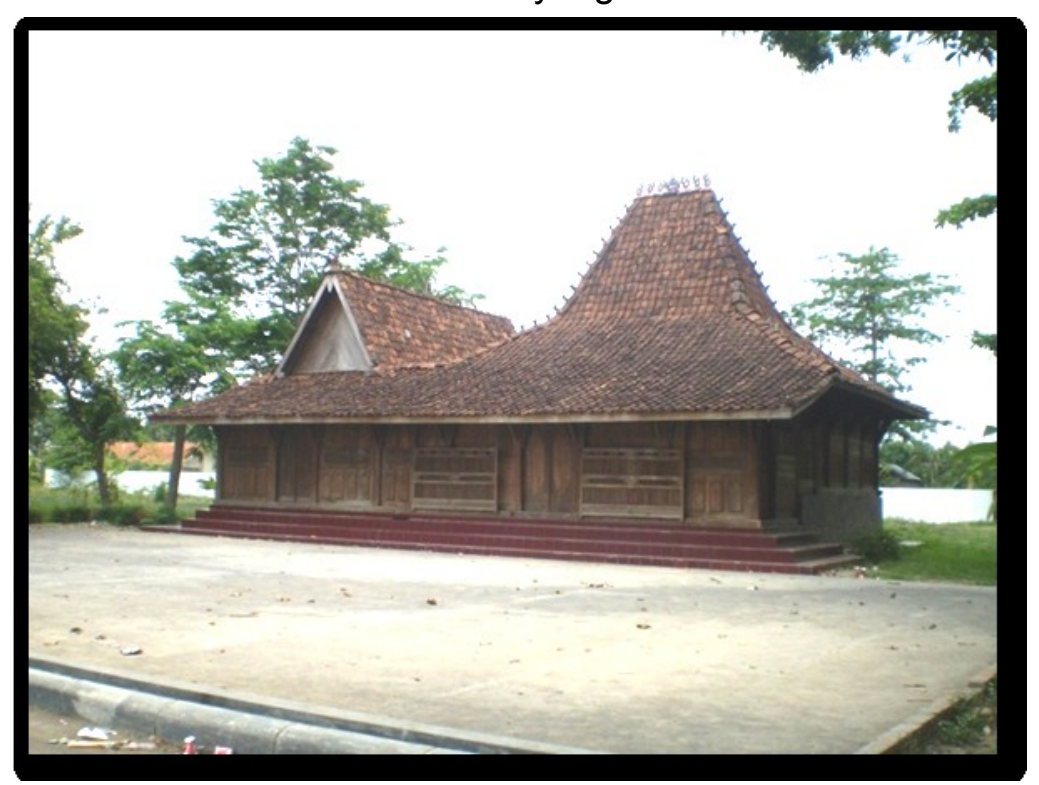

Foto 1. Rumah Pencu yang terdapat di Museum Kretek Kudus 
Tabel 1. Hasil Inventarisasi rumah tradisional di Kudus

\begin{tabular}{|c|c|c|c|}
\hline Kecamatan & Desa & Wilayah & Jumlah \\
\hline Kota & Langgar Dalem & Kudus Kulon & 14 \\
\hline Kota & Kauman & Kudus Kulon & 12 \\
\hline Kota & Kerjasan & Kudus Kulon & 13 \\
\hline Kota & Damaran & Kudus Kulon & 5 \\
\hline Kota & Sunggingan & Kudus Kulon & 6 \\
\hline Kota & Purwosari & Kudus Kulon & 5 \\
\hline Kota & Janggalan & Kudus Kulon & 1 \\
\hline Kota & kajeksan & Kudus Kulon & 2 \\
\hline Kota & Panjunan & Kudus Wetan & 3 \\
\hline Kota & Demaan & 2 \\
\hline Jumlah total rumah & \multicolumn{2}{|l}{} \\
\hline \multicolumn{2}{|c|}{}
\end{tabular}

Sumber: Dinas Pariwisata dan Kebudayaan Kabupaten Kudus tahun 2007.

Berbeda dengan survei yang telah dilakukan oleh Dinas Pariwisata dan Kebudayaan Kabupaten Kudus yang dilakukan pada tahun 2007, daftar rumah Pencu di Kabupaten Kudus, berdasarkan survei yang dilakukan oleh penulis hanya berhasil mendata 55 rumah Pencu yang tersebar di Kawasan Kudus Kulon dan Kudus Wetan.

Adanya perbedaan jumlah rumah Pencu yang didata oleh Dinas Pariwisata dan Kebudayaan Kabupaten Kudus dengan data dari penulis menunjukkan adanya tingkat penurunan jumlah rumah Pencu. Penurunan jumlah rumah tersebut terkait dengan eksistensi rumah $P$ encu yang oleh bermacam faktor mengalami penurunan antara lain adalah penjualan dari rumah tradisional tersebut.

Hasil penelitian menunjukkan bahwa arsitektur rumah Pencu terbagi dalam beberapa variabel yakni dinding, lantai, tata ruang, ornamen, dan tipologi rumah Pencu itu sendiri. Dari segi penggunaan dinding rumah Pencu memiliki variasi yang kemudian terbagi dalam beberapa kategori dinding ruang, yaitu dinding pada bagian jogosatru yang merupakan dinding pembatas antar ruang jogosatru dengan ruang senthong. Ke dua, dinding bagian depan rumah atau sering disebut dengan istilah lokal sebagai tritisan, yang merupakan dinding pembatas ruang tritisan dengan ruang jogosatru. Ketiga adalah dinding pembatas ruang bagian samping kiri - kanan dan bagian belakang rumah. Berdasarkan klasifikasi tersebut didapatkan beberapa jenis dinding dengan penggunaan bahan yang berbeda, yaitu penggunaan dinding dari kayu, tembok, dan bambu.

Lantai yang digunakan dalam rumah Pencu yang terdapat di Kabupaten Kudus adalah lantai kayu, lantai plester, lantai tegel, lantai tegel polos, lantai tegel bermotif, dan lantai keramik. Pembagian ruang yang terdapat di rumah Pencu memiliki kesamaan ruang, kecuali keletakan pawon, pakiwan, dan terdapatnya pagar kilungan yang tidak semuanya memilikinya. Variabel yang terakhir adalah ornamen ukir. Ornamen yang terdapat di rumah Pencu diklasifikasikan dengan tujuan untuk memudahkan penulis dalam melihat persebaran ornamen ukir pada rumah Pencu di Kabupaten Kudus. Dalam membuat klasifikasi tipe ukir, penulis medapatkan tiga tipe ukir, yaitu rumah dengan tipe ukir A, B, dan C. Pengklasisifikasian tersebut didasarkan pada jumlah motif ukir yang terdapat pada masing-masing rumah dengan ketentuan motif ukir yang kurang dari 15 ornamen digolongkan pada tipe ukir $\mathrm{C}$, rumah dengan jumlah motif antara $16-30$ ornamen di klasifikasikan ke dalam tipe ukir $\mathrm{B}$, sedangkan rumah yang memiliki lebih dari 31 motif ukir diklasifikasikan ke dalam tipe ukir C. 
Tabel 2. Tipe rumah Pencu yang terdapat di Kudus.

\begin{tabular}{|c|c|c|c|c|c|c|c|c|c|c|c|c|c|}
\hline \multirow{2}{*}{$\begin{array}{l}\text { Kode } \\
\text { Rumah }\end{array}$} & \multirow{2}{*}{ Pemilik } & \multirow{2}{*}{ Desa } & \multirow{2}{*}{ Wilayah } & \multirow{2}{*}{$\begin{array}{l}\text { Pembatas } \\
\text { jogosatru- } \\
\text { senthong }\end{array}$} & \multicolumn{3}{|c|}{ Dinding pembatas bagian luar } & \multirow{2}{*}{$\begin{array}{c}\text { Pagar } \\
\text { Kilungan }\end{array}$} & \multirow{2}{*}{ Pawon } & \multirow{2}{*}{ Pakiwan } & \multirow{2}{*}{ Lantai } & \multirow{2}{*}{$\begin{array}{l}\text { Tipe } \\
\text { Ukir }\end{array}$} & \multirow{2}{*}{$\begin{array}{c}\text { Tipe } \\
\text { Rumah } \\
\text { Pencu }\end{array}$} \\
\hline & & & & & Depan & Samping & Belakang & & & & & & \\
\hline RP 01 & Yono & Kajeksan & Kudus Kulon & Kayu & Kayu & Tembok & Tembok & Tidak ada & Tidak ada & Tidak ada & Plester & $B$ & $B$ \\
\hline RP 02 & & Kajeksan & Kudus Kulon & Kayu & Kayu & Tembok & Tembok & Tidak ada & Tidak ada & Tidak ada & Plester & C & $\mathrm{E}$ \\
\hline RP 03 & & Kerjasan & Kudus Kulon & Kayu & Kayu & Tembok & Tembok & Tidak ada & Kiri & Kiri & Tegel Polos & $\mathrm{C}$ & $E$ \\
\hline RP 04 & Marno & Kauman & Kudus Kulon & Kayu & Kayu & Kayu & Kayu & Ada & Kiri & Kiri & Keramik & A & A \\
\hline RP 05 & $\mathrm{Hj}$. Maziroh & Kerjasan & Kudus Kulon & Kayu & Kayu & Tembok & Tembok & Ada & Kanan & Kanan & Tegel Polos & A & A \\
\hline RP 06 & & $\begin{array}{l}\text { Langgar } \\
\text { Dalem }\end{array}$ & Kudus Kulon & Tembok & Kayu & Tembok & Tembok & Ada & Kanan & Kanan & Keramik & C & $\mathrm{F}$ \\
\hline RP 07 & Hj. Munjaenah & Kerjasan & Kudus Kulon & Kayu & Kayu & Tembok & Tembok & Ada & Kiri & Kiri & $\begin{array}{c}\text { Tegel } \\
\text { Bermotif }\end{array}$ & A & A \\
\hline RP 08 & Toha & Kerjasan & Kudus Kulon & Kayu & Kayu & Tembok & Tembok & Tidak ada & Kanan & Kanan & Tegel Polos & $\mathrm{C}$ & $\mathrm{E}$ \\
\hline RP 09 & $\begin{array}{l}\text { Ny.Masruhan, } \\
\text { Alm. }\end{array}$ & Krandon & Kudus Kulon & Bambu & Kayu & Tembok & Tembok & Tidak ada & Kiri & Kiri & Plester & C & $\mathrm{F}$ \\
\hline $\mathrm{RP} 10$ & M. Sodakoh & Krandon & Kudus Kulon & Tembok & Kayu & Tembok & Tembok & Tidak ada & Kiri & Tidak ada & Plester & $\mathrm{C}$ & $\mathrm{F}$ \\
\hline RP 11 & $\begin{array}{l}\text { H. Abdul } \\
\text { Wahab }\end{array}$ & Kauman & Kudus Kulon & Kayu & Kayu & Tembok & Tembok & Tidak ada & Kanan & Kanan & $\begin{array}{c}\text { Tegel } \\
\text { Bermotif }\end{array}$ & B & C \\
\hline RP 12 & Jamaludin & Kauman & Kudus Kulon & Tembok & Kayu & Tembok & Tembok & Tidak ada & Kiri & Tidak ada & Keramik & $B$ & $\mathrm{D}$ \\
\hline RP 13 & Sakir & Kauman & Kudus Kulon & Kayu & Kayu & Tembok & Tembok & Tidak ada & Kanan & Tidak ada & Keramik & $\mathrm{B}$ & C \\
\hline RP 14 & Ny. Siti Aminah & Kauman & Kudus Kulon & Kayu & Kayu & Tembok & Tembok & Tidak ada & $\begin{array}{c}\text { Kanan, } \\
\text { Kiri }\end{array}$ & Kiri & $\begin{array}{c}\text { Tegel } \\
\text { Berwarna }\end{array}$ & C & E \\
\hline RP 17 & Munawir & Kauman & Kudus Kulon & Tembok & Kayu & Tembok & Tembok & Tidak ada & Kiri & Kiri & Plester & $C$ & $\mathrm{~F}$ \\
\hline RP 18 & Masad & Kauman & Kudus Kulon & Kayu & Kayu & Tembok & Tembok & Tidak ada & Kanan & Kanan & Plester & $\mathrm{C}$ & $E$ \\
\hline RP 19 & Noor Chooliha & Kauman & Kudus Kulon & Tembok & Kayu & Tembok & Tembok & Ada & Kanan & Tidak ada & Tegel Polos & C & $\mathrm{F}$ \\
\hline RP 20 & Zaroh & $\begin{array}{l}\text { Loram } \\
\text { Kulon }\end{array}$ & Kudus Wetan & Tembok & Kayu & Tembok & Tembok & Tidak ada & Kanan & Tidak ada & Keramik & C & $\mathrm{F}$ \\
\hline RP 21 & $\begin{array}{l}\text { PEMDA } \\
\text { KUDUS }\end{array}$ & $\begin{array}{c}\text { Getas } \\
\text { Pejaten }\end{array}$ & Kudus Wetan & Kayu & Kayu & Kayu & Kayu & Tidak ada & Kanan & Kanan & $\begin{array}{c}\text { Keramik, } \\
\text { Kayu }\end{array}$ & A & B \\
\hline RP 22 & H. Muslim Cs. & Demaan & Kudus Wetan & Tembok & Kayu & Tembok & Tembok & Ada & Kanan & Tidak ada & Keramik & $\mathrm{C}$ & $\mathrm{F}$ \\
\hline RP 23 & & Demaan & Kudus Wetan & Kayu & Kayu & Tembok & Tembok & Tidak ada & Kiri & Kiri & Keramik & $\mathrm{C}$ & $\mathrm{E}$ \\
\hline RP 24 & Endang E. & Glantengan & Kudus Wetan & Kayu & Kayu & Tembok & Tembok & Tidak ada & Kiri & Kiri & Keramik & C & $\mathrm{E}$ \\
\hline
\end{tabular}




\begin{tabular}{|c|c|c|c|c|c|c|c|c|c|c|c|c|c|}
\hline RP 25 & Sirin & Kajeksan & Kudus Kulon & Kayu & Kayu & Tembok & Tembok & Tidak ada & Kanan & Kanan & Plester & C & E \\
\hline RP 26 & Ali Ahsan & $\begin{array}{l}\text { Langgar } \\
\text { Dalem }\end{array}$ & Kudus Kulon & Tembok & Kayu & Tembok & Tembok & Tidak ada & Kanan & Tidak ada & Keramik & C & $\mathrm{F}$ \\
\hline RP 27 & & Janggalan & Kudus Kulon & Kayu & Kayu & Tembok & Tembok & Tidak ada & Tidak ada & Tidak ada & Plester & C & $E$ \\
\hline RP 28 & Ny. Ismawati & Kerjasan & Kudus Kulon & Kayu & Kayu & Tembok & Tembok & Tidak ada & Tidak ada & Tidak ada & Plester & $C$ & $E$ \\
\hline RP 29 & Ny. Rihana & Kerjasan & Kudus Kulon & Kayu & Kayu & Kayu & Kayu & Ada & Kanan & Kanan & Keramik & A & A \\
\hline RP 30 & Asikin & Damaran & Kudus Kulon & Kayu & Kayu & Kayu & Kayu & Ada & Kanan & Tidak ada & $\begin{array}{c}\text { Tegel } \\
\text { Bermotif }\end{array}$ & A & A \\
\hline RP 31 & & Damaran & Kudus Kulon & Kayu & Kayu & Tembok & Tembok & Ada & Kanan & Tidak ada & Keramik & $C$ & $E$ \\
\hline RP 32 & Dahlan & $\begin{array}{l}\text { Langgar } \\
\text { Dalem }\end{array}$ & Kudus Kulon & Kayu & Kayu & Tembok & Tembok & Ada & Kiri & Tidak ada & $\begin{array}{c}\text { Tegel } \\
\text { Bermotif }\end{array}$ & C & $E$ \\
\hline RP 34 & Son Haji & Kauman & Kudus Kulon & Kayu & Kayu & Tembok & Tembok & Ada & Kiri & Kiri & Tegel Polos & $\mathrm{C}$ & $E$ \\
\hline RP 35 & Salim & Kauman & Kudus Kulon & Tembok & Kayu & Tembok & Tembok & Ada & Tidak ada & Kiri & Keramik & C & $\mathrm{F}$ \\
\hline RP 36 & Rofi'i & Kauman & Kudus Kulon & Kayu & Kayu & Tembok & Tembok & Ada & Kanan & Kanan & Tegel Polos & C & $E$ \\
\hline RP 37 & Khamim & Kauman & Kudus Kulon & Tembok & Kayu & Tembok & Tembok & Ada & Kiri & Tidak ada & Tegel Polos & C & $\mathrm{F}$ \\
\hline RP 38 & Desa Kerjasan & Kauman & Kudus Kulon & Kayu & Kayu & Tembok & Tembok & Tidak ada & Kiri & Kiri & $\begin{array}{c}\text { Tegel } \\
\text { Berwarna }\end{array}$ & C & $E$ \\
\hline RP 39 & H. Sya'roni & Kerjasan & Kudus Kulon & Tembok & Kayu & Tembok & Tembok & Tidak ada & Kiri & Kiri & Plester & $\mathrm{C}$ & $\mathrm{F}$ \\
\hline RP 40 & & Kerjasan & Kudus Kulon & Kayu & Kayu & Kayu & Kayu & Ada & Kiri & Kiri & Plester & $C$ & $E$ \\
\hline RP 41 & & Kerjasan & Kudus Kulon & Kayu & Kayu & Tembok & Tembok & Ada & Kiri & Kiri & Keramik & C & $E$ \\
\hline RP 43 & Sukriyah & Demangan & Kudus Kulon & Tembok & Kayu & Tembok & Tembok & Ada & Kanan & Kiri & Tegel Polos & $\mathrm{C}$ & $F$ \\
\hline RP 44 & H. Fattah & Demangan & Kudus Kulon & Tembok & Kayu & Tembok & Tembok & Ada & Kiri & Kiri & Tegel Polos & C & $\mathrm{F}$ \\
\hline RP 45 & H. D.M. Ridwan & Demaan & Kudus Wetan & Bambu & Kayu & Tembok & Tembok & Ada & Kanan & Kanan & Tegel Polos & C & $\mathrm{F}$ \\
\hline RP 46 & Arif Farhan Nor & Sunggingan & Kudus Wetan & Kayu & Kayu & Kayu & Tembok & Ada & Kanan & Kanan & Tegel Polos & B & C \\
\hline RP 47 & & Demangan & Kudus Kulon & Tembok & Kayu & Tembok & Tembok & Tidak ada & Kiri & Tidak ada & Tegel Polos & $\mathrm{C}$ & $\mathrm{F}$ \\
\hline RP 48 & & Demangan & Kudus Kulon & Tembok & Kayu & Bambu & Bambu & Tidak ada & Kanan & Tidak ada & Tegel Polos & C & $\mathrm{F}$ \\
\hline RP 49 & Rozzi & Purwosari & Kudus Kulon & Kayu & Kayu & Tembok & Tembok & Ada & Kanan & Tidak ada & Keramik & C & $E$ \\
\hline RP 50 & A.K. Machine & Damaran & Kudus Kulon & Kayu & Kayu & Tembok & Tembok & Ada & Kanan & Tidak ada & Keramik & C & $E$ \\
\hline RP 51 & & Kajeksan & Kudus Kulon & Tembok & Kayu & Tembok & Tembok & Tidak ada & Tidak ada & Tidak ada & Tegel Polos & C & $\mathrm{F}$ \\
\hline RP 52 & & Kauman & Kudus Kulon & Kayu & Kayu & Tembok & Tembok & Ada & Kiri & Kiri & Keramik & B & C \\
\hline RP 53 & A. H. Sjahbini & Kerjasan & Kudus Kulon & Kayu & Kayu & Tembok & Tembok & Ada & Kanan & Tidak ada & Tegel Polos & B & C \\
\hline RP 54 & & Kerjasan & Kudus Kulon & Kayu & Kayu & Tembok & Tembok & Ada & Kanan & Kanan & Plester & B & C \\
\hline RP 55 & Fatkhurohman & Demangan & Kudus Kulon & Kayu & Kayu & Tembok & Tembok & Ada & Kiri & Tidak ada & Keramik & $\mathrm{C}$ & $E$ \\
\hline
\end{tabular}




\section{ANALISIS POLA PERSEBARAN RUMAH PENCU DI KUDUS}

Menurut Renfrew dan Bahn (1991: 85), hierarki situs harus disimpulkan dari data arkeologis secara langsung tanpa banyak bergantung pada data tertulis. Untuk kepentingan tersebut maka ada beberapa hal yang harus dipertimbangkan sebelum menentukan hierarki sebuah situs, antara lain ukuran situs, lokasi situs, material yang dapat menunjukkan aktivitas yang terorganisir, dan artefak.

Di dalam penelitian ini digunakan analisis keruangan untuk mengetahui hubungan antar komponen pada rumah Pencu yaitu arsitektur dan tipologinya. Hubungan tersebut kemudian menjadi dasar rekonstruksi struktur keruangan sekaligus menggambarkan tingkat hierarki antar komponen pada distribusi persebaran rumah Pencu di Kabupaten Kudus. Untuk kepentingan tersebut, penulis mengadopsi beberapa variabel yang dikemukakan oleh Vogt dan kemudian disempurnakan oleh Willey dalam menentukan struktur dan hierarki sebuah pemukiman.

Untuk mempermudah analisis maka sebaran rumah Pencu yang terdapat di Kabupaten Kudus dibagi dalam beberapa kelompok. Pengelompokan tersebut didasarkan pada beberapa variable yang terkait dengan wilayah (fitur batas alam) yang berupa Kali Gelis yang membagi Kudus menjadi dua wilayah yaitu Kudus Kulon dan Kudus Wetan, toponim/desa, komponen dan struktur individual pada masing-masing rumah Pencu (Tabel 3).

Tabel 3. Pengelompokan rumah Pencu di Wilayah Kudus

\begin{tabular}{|c|c|c|c|c|}
\hline No & Kelompok & Wilayah & Desa/Toponim & Kode rumah \\
\hline \multirow[t]{9}{*}{1} & \multirow[t]{9}{*}{ I } & \multirow[t]{9}{*}{ Kudus Kulon } & Kauman & $\begin{array}{l}\text { RP } 04, \mathrm{RP} 11, \mathrm{RP} 12, \mathrm{RP} \\
13, \mathrm{RP} 14, \mathrm{RP} 15, \mathrm{RP} 16, \\
\mathrm{RP} 17, \mathrm{RP} 18, \mathrm{RP} 19, \mathrm{RP} \\
34, \mathrm{RP} 35, \mathrm{RP} 36, \mathrm{RP} 37, \\
\mathrm{RP} 38, \mathrm{RP} 52\end{array}$ \\
\hline & & & Kerjasan & $\begin{array}{l}\text { RP } 03, \text { RP } 05, \text { RP } 07, \text { RP } \\
08, \text { RP } 28, \text { RP } 29, \text { RP } 39 \text {, } \\
\text { RP } 40, \text { RP } 41, \text { RP } 42, \text { RP }\end{array}$ \\
\hline & & & Langgar Dalem & RP 06, RP 26, RP 27 \\
\hline & & & Kajeksan & $\begin{array}{l}\text { RP 01, RP 02, RP 25, RP } \\
33, R P 51\end{array}$ \\
\hline & & & Damaran & $\operatorname{RP} 30, \mathrm{RP} 31, \mathrm{RP} 50$ \\
\hline & & & Demangan & $\begin{array}{l}\text { RP 43, RP 44, RP 47, RP } \\
\text { 48, RP 55 }\end{array}$ \\
\hline & & & Krandon & RP 09, RP 10 \\
\hline & & & Janggalan & RP 27 \\
\hline & & & Purwosari & RP 49 \\
\hline \multirow[t]{5}{*}{2} & \multirow[t]{5}{*}{ II } & \multirow[t]{5}{*}{ Kudus Wetan } & Demaan & RP 22, RP 23, RP 45 \\
\hline & & & Glantengan & RP 24 \\
\hline & & & Sunggingan & RP 46 \\
\hline & & & Getas Pejaten & RP 21 \\
\hline & & & Loram Kulon & RP 20 \\
\hline
\end{tabular}

Di wilayah Kudus Kulon persebaran rumah Pencu berjumlah 28 rumah dengan kepadatan sebarannya terdapat di Desa Kauman dengan jumlah rumah 16 rumah Pencu, Desa Kerjasan 12 rumah, Desa Kajeksan 5 rumah, Desa Demangan 5 rumah, Desa Langgar Dalem 3 rumah, Desa Damaran 3 rumah, Desa Krandon 2 rumah, Desa Janggalan 1 rumah, dan Desa Purwosari 1 rumah. Sedangan di wilayah Kudus Wetan persebaran rumah Pencu memiliki jumlah 7 rumah dengan sebaran rumah paling banyak di Desa Demaan dengan 4 rumah, Desa Glantengan 1 rumah, Desa Sunggingan 1 rumah, Desa Getas Pejaten 1 rumah, dan di Desa Loram Kulon 1 rumah. 
Penggunaan tipologi dalam penelitian ini memiliki tujuan untuk mengelompokkan persebaran rumah Pencu berdasarkan dari berbagai variabel analisis, yaitu variabel arsitektur, tata ruang, dan ornamen ukir. Berdasarkan ketiga variabel tersebut diperoleh enam tipe rumah Pencu yang terdapat di Kabupaten Kudus, yaitu:

1. Tipe A

Rumah Pencu dengan tipe $A$, terbentuk dari variabel-variabel yaitu rumah Pencu dengan tipe ukir A, dan memiliki kelengkapan arsitektur (pembatas jogosatrusenthong, pembatas tritisan, dinding pembatas rumah bagian samping kanan dan belakang, keseluruhan terbuat dari kayu), terdapat pagar kilungan, dan memiliki kelengkapan tata letak ruang yaitu terdapatnya pawon dan pakiwan.

2. Tipe B

Rumah Pencu tipe B terbentuk dari variabel yaitu memiliki tipe ukir A, kelengkapan arsitektur yaitu pembatas jogosatru - senthong dari kayu, dinding samping kanan-kiri dan belakang dari tembok.

3. Tipe C

Rumah Pencu dengan tipe ukir B, kelengkapan arsitektur pembatas ruang jogosatru senthong dari kayu, pembatas dinding bagian samping kanan, kiri, dan belakang rumah dari tembok.

4. Tipe D

Rumah Pencu dengan tipe ukir B, kelengkapan arsitektur pembatas ruang jogosatru senthong dari dinding tembok/bambu, pembatas dinding bagian samping kanan, kiri, dan belakang rumah dari tembok.

5. Tipe $\mathrm{E}$

Rumah Pencu dengan tipe ukir C, kelengkapan arsitektur pembatas ruang jogosatru senthong dari kayu, pembatas dinding bagian samping kanan, kiri, dan belakang rumah dari tembok.

6. Tipe $F$

Rumah Pencu dengan tipe ukir $\mathrm{C}$, kelengkapan arsitektur pembatas ruang jogosatru senthong dari dinding tembok/bambu, pembatas dinding bagian samping kanan, kiri, dan belakang rumah dari tembok 
Peta 1. Sebaran Rumah Pencu Berdasarkan Tipologinya

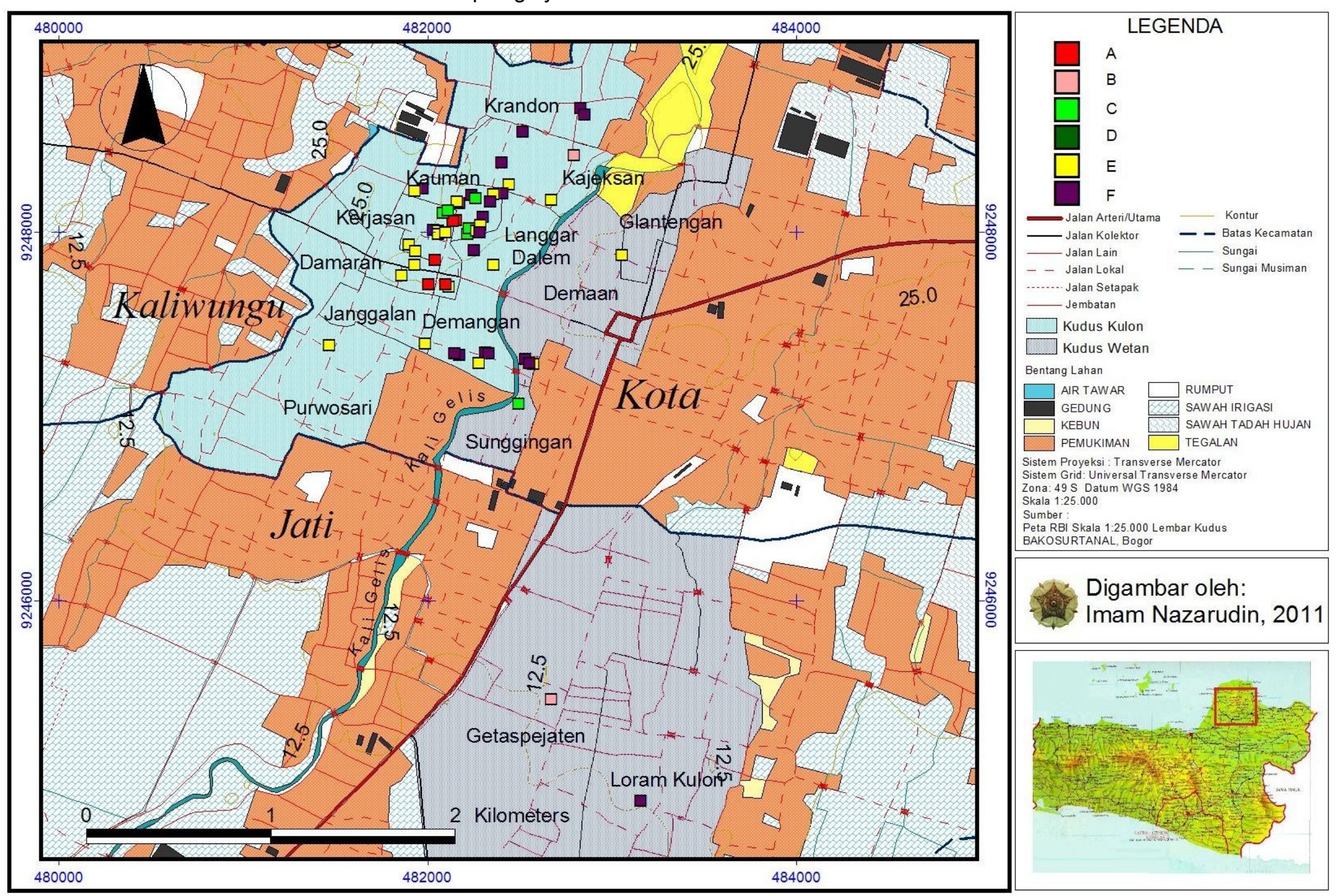


Peta 2. Sebaran rumah Pencu terhadap situs arkelogi di Kudus Kulon dan Kudus Wetan

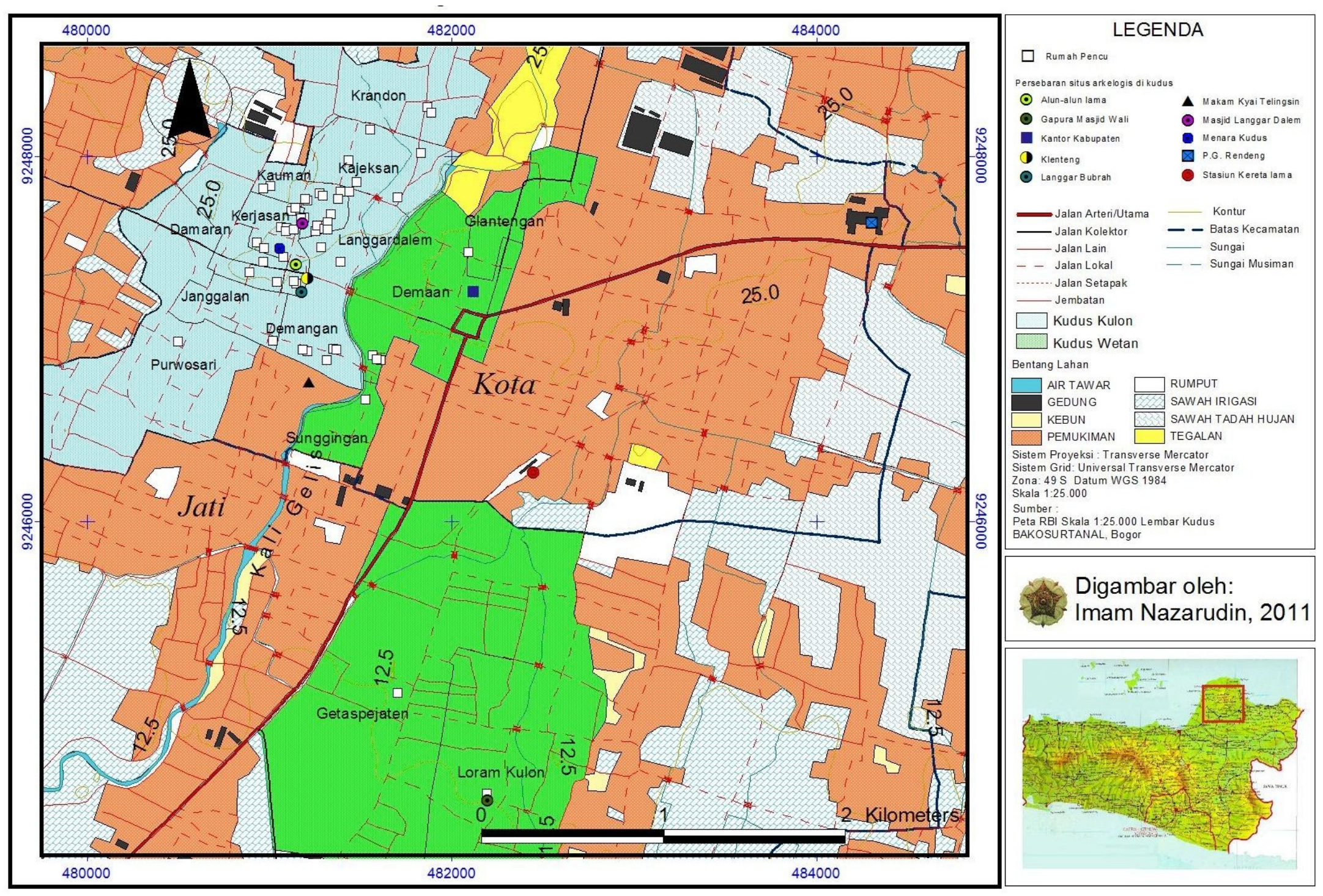


Dari data mengenai klasifikasi terhadap tipologi rumah Pencu dihasilkan 6 tipe rumah Pencu. Rumah Pencu dengan tipe A berdasarkan tipologinya terdapat 5 rumah Pencu yaitu rumah dengan kode RP 04, RP 05, RP 07, RP 29, dan RP 30 dengan persentase 9,09\% dari jumlah rumah Pencu di Kabupaten Kudus. Rumah Pencu dengan tipe B sebanyak 2 rumah, yakni RP 01 dan RP 21 dengan persentase sebanyak 3,64\%. Rumah Pencu dengan tipe dengan C sebanyak 6 rumah, yaitu RP 11, RP 13, RP 46, RP 52, RP 53, dan RP 54 dengan persentase sebanyak 10,91\%. Tipe D terdapat di satu rumah saja, dengan persentase sebanyak $1,82 \%$, yaitu rumah dengan kode RP 12 milik bapak Jamaludin di Desa Kauman. Rumah Pencu dengan tipe E sebanyak 21 rumah dengan persentase $38,18 \%$, sedangkan untuk tipe $F$ sebanyak 20 rumah dengan persentase sebanyak $36,36 \%$.

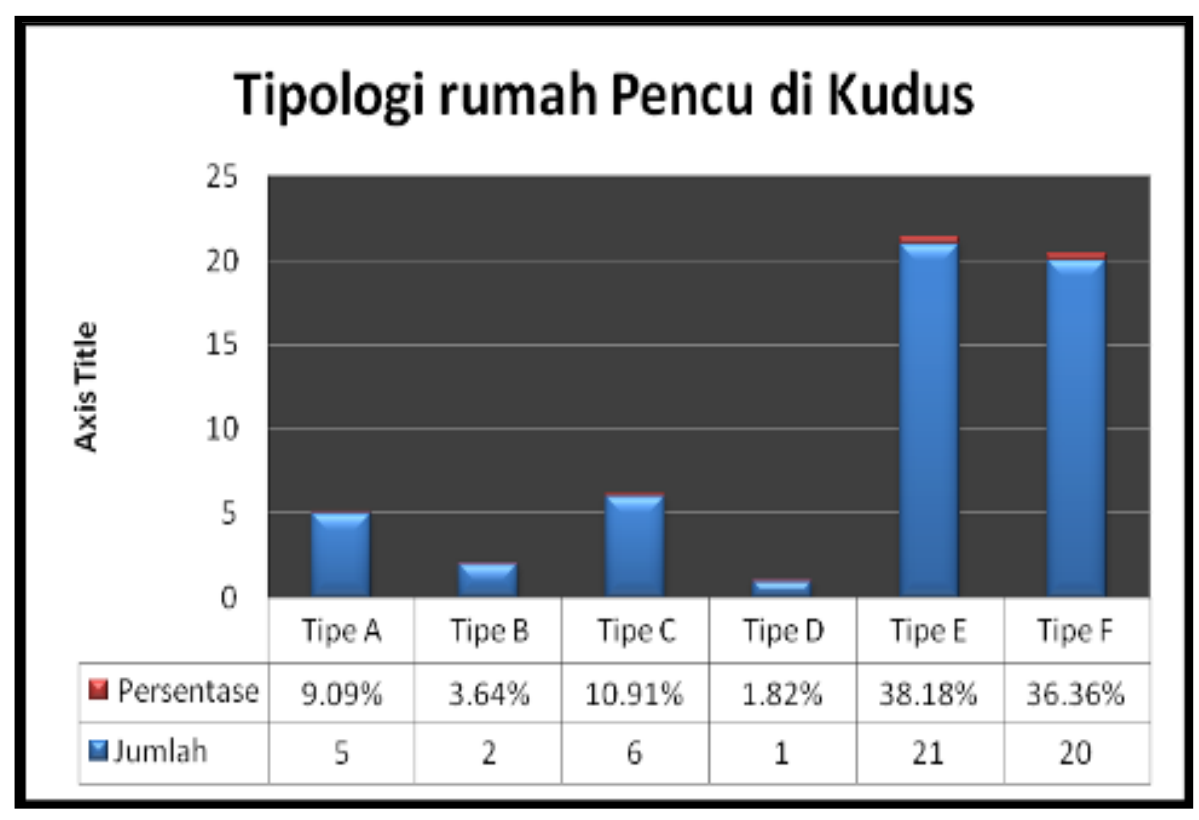

Grafik 1. Persentase dan jumlah tipe rumah Pencu di Kudus.

Terdapatnya tipe rumah Pencu di Kudus memberikan gambaran mengenai keadaan sosial masyarakat Kudus pada masa lalu. Di mana klasifikasi tersebut berdasarkan tabel 2 , grafik 1 , dan peta 1 menggambarkan dominasi tipe $E$ dan $F$, tipe $B$ dan $D$ merupakan tipe yang minoritas, sedangkan tipe $A$ dan $C$ merupakan medium dalam hasil klasifikasi tersebut. Tipe A merupakan tipe rumah tertinggi yang dihasilkan dari kondisi budaya masyarakat pada masa lalu. Kemungkinan besar tipe A dan B merupakan rumah yang di miliki oleh para saudagar/keturunan bangsawan yang ada di Kudus. Tipe $C$ dan D merupakan tingkatan kedua, sedangkan tipe $\mathrm{E}$ dan $\mathrm{F}$ merupakan tingkatan ketiga atau paling bawah dari tingkatan rumah Pencu yang ada di Kudus ini.

Tipologi rumah Pencu dikedua wilayah tersebut juga membentuk adanya hirarki dari rumah Pencu itu sendiri. Adanya hierarki tersebut dibuktikan dengan memusatnya rumah tipe ukir A pada pada wilayah pusat dari Kudus Kulon di daerah Damaran, Kauman, dan Kerjasan, kemudian diikuti dengan tipe $C$ dan $D$ yang berada di daerah penyangga dari wilayah Kudus kulon yaitu Kerjasan bagian timur dan di Kauman bagian tengah dan selatan. Sedangkan tipe $E$ dan F mengelilingi dari tipe A, C, dan D. Tipe E dan F tersebar di kedua wilayah penelitian yaitu di wilayah Kudus Kulon dan Kudus Wetan. Sementara tipe yang terdapat di dua wilayah tersebut yaitu rumah dengan Kode RP 01 dan RP 21 merupakan rumah yang sudah tidak memiliki konteks sejarah. Adanya hal tesebut disebabkan karena RP 01 (Kajeksan) telah mengalami perubahan arsitektur dari tipe $\mathrm{F}$ akibat diadakan renovasi oleh pemilik rumah tersebut pada tahun 2008 . Untuk tipe B yang terdapat di wilayah Kudus Wetan yaitu RP 21 (Getas pejaten) merupakan rumah yang tidak asli dibangun di tempat tersebut melainkan berasal dari wilayah Kudus Kulon 
yang kemudian disusun ulang (dengan sistem knock down) di tempat tersebut untuk dijadikan museum.

Semakin keluar dari wilayah Kauman, Kerjasan, dan Damaran, tipe rumah Pencu mengalami degradasi tingkatan dari tipe paling atas yaitu tipe A ke tipe bawah yaitu tipe $E$ dan F. Adanya pemusatan tipe rumah tersebut sangat erat kaitannya dengan kondisi di Kudus Kulon dan Kudus Wetan pada masa lalu. Di mana telah diungkap di atas bahwa Kudus Kulon merupakan pusat dari Kebudayaan Jawa Islam di Kudus tepatnya di daerah sekitar dari masjid menara Kudus (Desa Kauman, Desa Damaran, dan Desa Kerjasan), sedangkan daerah disekitarnya merupakan daerah penyangga dari wilayah tersebut. Semakin jauh dari lokasi pusat maka akan semakin rendah tingkatan tipe dari rumah Pencu tersebut.

Terkait dengan konteks temuan, maka rumah Pencu di Wilayah Kudus Kulon dan Kudus Wetan masuk dalam konteks primer yang berhubungan dengan penggunaan (use related context) karena pada dasarnya rumah tersebut masih difungsikan sebagai tempat tinggal atau hunian oleh pemiliknya sejak rumah tersebut didirikan.

Unsur-unsur pemukiman di wilayah Kudus Kulon dan Kudus Wetan tidak hanya terdiri atas rumah tradisional, dalam penelitian ini adalah rumah Pencu dan juga rumah hunian modern, melainkan juga unsur-unsur seperti pasar, alun-alun, bangunan umum, kuburan, dan jalan. Data persebaran rumah Pencu di Kudus terbagi menjadi dua kelompok yaitu di wilayah Kudus Kulon (Kelompok I) dan di wilayah Kudus Wetan (Kelompok II). Berdasarkan peta 2., terlihat persebaran rumah Pencu memiliki kecenderungan mengelompok di daerah Kudus Kulon dengan berpusat di daerah sekitar Masjid Menara Kudus. Sedangkan di wilayah Kudus Wetan rumah Pencu terpusat di timur dari sungai Gelis yang berada di sebelah barat dari Kantor Kabupaten Kudus dan di bagian selatan dari wilayah Kudus Wetan terdapat situs arkeologis berupa Gapura Masjid Wali yang tepat di sebelah utaranya terdapat rumah Pencu.

Berkaitan dengan sebaran rumah Pencu di kedua wilayah tersebut, Walter Chhirstaller mengemukakan tentang terori pemusatan pemukiman (central place theory) yang menyatakan bahwa syarat ideal suatu kota pemukiman pusat adalah bila jarak yang sama satu dengan yang lain dan akan dikelilingi oleh pemukiman yang lebih kecil sebagai pemukiman penyangga sehingga terbentuk pola heksagonal pada bentang alam datar (Walter Christaller dalam Renfrew C. dan Paul Bahn, 1996: 170-171). Adanya teori ini digunakan dalam mempermudah keragaman sebaran rumah Pencu yang terdapat di Kudus.

Terpusatnya rumah-rumah Pencu di wilayah Kudus Kulon (Kelompok I) mengindikasikan pada wilayah Kudus Kulon, hubungan antar situs dan rumah Pencu memiliki keterkaitan yang sangat tinggi hal ini terbukti dengan masih bertahannya rumah Pencu yang memiliki kecenderungan memusat di wilayah sekitar kompleks Masjid Menara Kudus. Hal ini diperkuat dengan konsentrasi rumah Pencu yang banyak terdapat pada toponim nama tempat yang memiliki tingkatan sosial yang menunjukkan nama jabatan/profesi pada masa lampau. Langgar Dalem menurut Wardani (1991) merupakan tempat tinggal dari Sunan Kudus, sedangkangkan Kauman merupakan pusat pemerintahan dan juga pusat pengembangan ilmu agama Islam pada masa itu. Rumah Pencu lainnya juga terdapat dalam toponim kota Kudus Lama seperti yang di kemukakan Wardani, adapun toponim dari keberadaan rumah Pencu tersebut di Kudus Kulon adalah Kajeksan, Damaran, Demangan, Janggalan, Kerjasan dan di Kudus Wetan adalah Sunggingan dan Demakan. Sedangkan tempat/desa yang terdapat rumah Pencu dan disebutkan dalam tulisan Wardani tersebut adalah di Desa Krandon, Purwosari (Kudus Kulon), Glantengan, Getas Pejaten, dan Loram Kulon (Kudus Wetan).

Menurut Turmudi pada masa Islam, Kudus Kulon berkembang lebih maju dibandingkan Kudus Wetan. Adanya sebaran arkeologis menunjukkan bahwa pada masa Islam, Kudus Kulon berkembang menjadi pusat kota Islam dengan pemukiman yang cukup padat dengan penduduknya yang bersifat homogen. Hal ini diperkuat dengan toponim yang menunjukkan profesi sosial pada masa itu yang tercermin sebagai nama tempat pada kawasan Kudus Kulon. Sedangkan di Kudus Wetan pada masa Islam 
cenderung belum berkembang dan menjadi daerah terisolir. Wilayah Kudus Wetan dihuni oleh masyarakat dari luar dan hal ini bisa dilihat dari adanya toponim yang menunjukkan etnis tersebut, yaitu; Panjunan, Demakan, dan Pekojan. Ditambahkan lagi oleh Turmudi (2005: 114 - 115).

Kudus Wetan berkembang lebih pesat pada masa Kolonial dengan di bangunnya jalan pos atau postweg sepanjang pantai utara pada tahun $1810 \mathrm{M}$ oleh dibawah pemerintahan Gubernur Jenderal Belanda pada waktu itu Daendels. Sejak saaat Kudus Wetan berkembang sebagai pusat pemerintahan Kolonial. Temuan arkeologis yang mewakili corak masa kolonial berupa Alun-alun Kota, Kantor Bupati, Stasiun Kereta Api, dan Pabrik Gula Rendeng yang semua berada di wilayah Kudus Wetan. Adapun tinggalan arkeologis yang bercorak Islam terdapat di bagian selatan dari wilayah ini, yaitu Gapura Masjid Wali yang terdapat di Dusun Kauman, Desa Loram Kulon.

Adanya perbedaan di ke dua wilayah dan dua budaya yang berbeda tersebut sangat mempengaruhi pola persebaran rumah Pencu yang terdapat di Kudus. Kecenderungan memusat tedapat di wilayah Kudus Kulon/kelompok I, sedangkan kecenderungan memencar terdapat di wilayah Kudus Wetan/kelompok II. Adanya perbedaan pola distribusi rumah $\mathrm{Pencu}$ ini sangat terkait dengan Kondisi Kudus pada masa lampau. Kudus Kulon merupakan sebuah daerah dengan tingkat tradisi dan budaya Islam dan Jawa yang masih tinggi dan bisa terlihat eksistensinya hingga saat ini. Sementara itu distribusi rumah Pencu di wilayah Kudus Wetan memiliki pola yang acak, dan kecenderungan ini sangat dipengaruhi oleh budaya masyarakat di kelompok II ini yang heterogen dari masa Islam sampai pada masa kolonial hingga sekarang.

Kecenderungan mengelompok pada Kelompok II ini hanya terdapat di bagian utara sebelah barat dari wilayah Kudus Wetan dan sangat dekat dengan Sungai Gelis yang merupakan batas alam pemisah dari wilayah Kudus Kulon dan Kudus Wetan. Di bagian tengah dan bagian timur dari wilayah Kudus Wetan yang banyak tinggalan kolonial tidak ditemukan adanya persebaran rumah Pencu. Hal ini berbeda jika lokasi tersebut terdapat situs Islam, rumah Pencu yang terdapat di bagian selatan dari wilayah Kudus Wetan yaitu RP 20 merupakan rumah Pencu yang terdapat di sebelah utara dari Masjid Wali yang merupakan tinggalan arkeologis yang bercorak Islam. Adanya pola persebaran yang cenderung memencar, mengindikasikan distribusi rumah Pencu di wilayah Kudus Wetan pada masa lalu mengikuti adanya pola pemukiman yang berkaitan dengan situs masa Islam. Hal ini diperkuat dengan tidak ditemukannya data rumah Pencu yang lokasinya terletak di dekat situs kolonial pada masa Belanda, seperti PG Rendeng, Stasiun Kereta Api, dan Kantor Bupati Kudus yang terdapat di wilayah Kudus Wetan (Peta 3).

Selain adanya pola sebaran rumah $P e n c u$ yang bersifat terpusat, perbedaan pola sebaran rumah Pencu di Kudus Kulon dan Kudus Wetan membuktikan bahwa bertahannya unsur-unsur tradisional dan kearifan lokal berkorelasi positif dengan kedekatannya terhadap pusat kebudayaan. Semakin dekat dengan pusat kebudayaan unsur-unsur tradisional dan kearifan lokal semakin kental dan eksistensi keberadaannya dapat bertahan sampai sekarang.

\section{PENUTUP}

Berdasarkan variabel arsitektur di atas, Penulis mengelompokkan rumah Pencu ke dalam 6 tipe rumah Pencu, yaitu tipe $A$, tipe $B$, tipe $C$, tipe $D$, tipe $E$, dan tipe $F$. Persebaran masing-masing tipe di atas menunjukan pola yang khas. Dari uraian di atas dapat di simpulkan bahwa Kudus Kulon memiliki variasi tipe yang lebih banyak dan kerapatannya sangat tinggi jika dibandingkan dengan Kudus Wetan yang memiliki kecenderungan kerapatan sangat rendah, dengan pola cenderung menyebar secara acak dan tidak membentuk klaster tertentu. Tipe rumah Pencu tersebut menunjukan adanya pola pemukiman pusat di mana semakin jauh dari lokasi pusat maka akan semakin rendah tingkatan tipe dari rumah Pencu tersebut. Kondisi ini menunjukkan bahwa Kudus Kulon merupakan poros/central dari kebudayaan tradisional masyarakat Kudus. Hal ini juga dibuktikan melalui kedekatan antara rumah Pencu dengan sebaran situs-situs masa 
Islam yang banyak terdapat di wilayah Kudus Kulon. Sedangkan di wilayah Kudus Wetan lebih banyak terdapat situs kolonial dibandingkan situs Islam.

Perbedaan pola sebaran rumah Pencu di Kudus Kulon dan Kudus Wetan membuktikan bahwa bertahannya unsur-unsur tradisional dan kearifan lokal berkorelasi positif dengan kedekatannya terhadap pusat kebudayaan yang terletak di sekitar kompleks masjid Menara Kudus. Semakin dekat dengan pusat kebudayaan unsur-unsur tradisional dan kearifan lokal semakin kental dan eksistensi keberadaannya dapat bertahan sampai sekarang. Dari aspek konservasi kawasan menunjukkan bahwa Kudus Kulon merupakan zona inti untuk melestarikan unsur-unsur tradisonal dan kebudayaan lokal masyarakat Kudus, termasuk keberadaan rumah Pencu.

\section{KEPUSTAKAAN}

Dinas Pariwisata dan Kebudayaan Kabupaten Kudus. 2007. Data Rumah Adat Kudus. Kudus: Dinas Pariwisata dan Kebudayaan Kabupaten Kudus.

Renfrew, C., \& Bahn, P. 1991. Archaeology: Theories, Methods and Practice. London: Thames and Hudson.

Said, Abdul Azis. 2004. Simbolisme Unsur Visual Rumah Tradisional Toraja dan Perubahan Aplikasinya Pada Desain Modern. Yogyakarta: Ombak.

Soekiman, Djoko. 2000. Kebudayaan Indis dan Gaya Hidup Masyarakat Pendukung di Jawa. Yogyakarta: Yayasan Bentang Budaya.

Turmudi. 2005. Latar Belakang Perbedaan Budaya Kudus Kulon dan Kudus Wetan. Skripsi Sarjana. Yogyakarta: Jurusan Arkeologi Fakultas IImu Budaya Universitas Gadjah Mada.

Vogt, Evon Z. 1956. An appraisal of prehistoric settlement patterns in the New World. In Prehistoric Settlement Patterns in the New World, ed. G. R. Willey, HIm. 173-182. Viking Fund Publications in Anthropology, No. 23.

Wardani, Lestari. 1991. Pola Perkampungan Kota Kudus Lama (Tinjauan Berdasarkan Toponim. Skripsi Sarjana. Yogyakarta: Fakultas Sastra Universitas Gadjah Mada.

Willey, G. R. 1953. Prehistoric Settlement Patterns in the Virú Valley, Perú. Washington DC. 